\title{
Lexical and visual choices in the representation of immigration in the Spanish press*
}

\author{
Eliecer Crespo Fernández and María Martínez Lirola
}

\begin{abstract}
Our goal in this paper is to shed some light on the treatment of immigration issues in the current Spanish press via the analysis of the visual and lexical choices used in the journalistic representation of immigration. With this in mind, taking Critical Discourse Analysis and Visual Grammar as theoretical paradigms, we will explore how immigration is represented in a representative sample of multimodal texts found in newspapers from Alicante, a province with a very high percentage of immigrants in Spain. To this end, we will analyse the image and the euphemistic lexical references to immigration in the headlines, subheadings and captions of the pieces of news that constitute our corpus. The findings obtained provide evidence for the fact that, in the majority of the texts analysed, a considerable number of lexical and visual elements do not contribute to a positive representation of immigrants and tend to provoke, whether consciously or not, discriminatory attitudes towards them.
\end{abstract}

Keywords: multimodality, Visual Grammar, Critical Discourse Analysis, euphemism, persuasive discourse, journalistic language.

\section{Introduction}

Though immigration ${ }^{1}$ is not a modern phenomenon, it was not until the mid-1990s that it became a matter of vital importance for Spanish public opinion. Due to the economic crisis and the accompanying high rate of unemployment in Europe in the 1980s, together with the closing of the borders of traditional recipient countries within the EU like Germany or France, societies that have seen relatively low levels of immigration until recently, such as Spain, Italy and Ireland, have developed into popular destinations for immigrants in the last two decades. More specifically, the growth of immigration to Spain was brought about, among other factors, by its admission to the EU, its proximity to the countries of the Maghreb (as Spain is the nearest European country for African emigrants to reach), the extent of its underground economy, and the regularization processes initiated in $1991 .^{2}$ The sharp increase in the influx of immigrants into Spain has triggered nationwide immigration debates and led to manifestations of intolerance, racism and xenophobia, together with other attitudes that have aimed at facilitating the integration of immigrants.

This ambivalence towards immigration is reflected, as one might expect, in the journalistic treatment of immigration. Indeed, immigration has become one of the most passionately contested issues in the media, and the second most important national issue after terrorism, sparking debate both within Spain and between Spain and other EU members (Ortega Pérez 2003). In this vein, we should be aware that the mass media are not only a source of knowledge and expression of opinions, but also, as Van Dijk (2000b) points out, "the main institution of ideological reproduction". The mass media are thus able to make a specific image of immigrants credible, and ultimately shape public opinion concerning immigration. As public opinion plays a crucial role in modern democratic societies, it goes without saying that it is important to understand how the media shape public opinion on such a controversial issue as immigration.

Among the mass media, the press is generally regarded as the most reliable source of information and the one with the greatest capacity to propagate ideologies, 
social conceptions and beliefs. In this regard, it seems evident that the role of the press can by no means be underestimated. As Cottle claims: "[...] the media can also serve to affirm social and cultural diversity and, moreover, provide crucial spaces in and through which imposed identities or the interests of others can be resisted, challenged and changed." (2000: 2). The press can therefore influence our knowledge, values and social codes through linguistic and visual means and we, as readers, should be aware of the methods of media manipulation in the daily production of news and commentary.

Given the power of the press in contemporary Western societies, it seems necessary to shed some light on the verbal and visual elements used by the media in the representation of immigration and immigrants. With this in mind, our main goal in this paper is to analyse the lexical and visual elements used by journalists in order to represent the image of the immigrant in multimodal texts, i.e., those which use more than one mode of meaning-making, verbal and non-verbal. ${ }^{3}$ To this end, taking Critical Discourse Analysis and Visual Grammar as theoretical paradigms, we will focus our attention on the lexical devices, namely euphemism, as well as the visual elements used by journalists to deal with immigration in the Alicante press. More specifically, we will analyse a selection of eight multimodal texts concerning immigration found in the daily newspapers La Verdad de Alicante (henceforth La Verdad) and Información published in March 2008. In each of these texts, we will focus on the image and, as far as the verbal element is concerned, we will analyse the discourses appearing in the caption of the photograph as well as those in the headline and subheading(s). We believe that these textual components are the ones that, together with the photograph, attract the readers' attention to the greatest extent - after all, the aim of headlines and subheadings is to capture the attention of the readership - and thus have a more obvious impact on the readers. In fact, these components of news items are more closely related to the visual element than the body of text. In other words, together with the photograph, headlines, subheadings and captions are the most eye-catching, attention-grabbing elements in a news item. This is especially true in the case of the caption, given that it explains the very image itself. ${ }^{4}$ In each of the verbal components of the articles analysed, we will concentrate on the analysis of euphemism, as this lexical device constitutes a particularly effective persuasive element at the journalist's disposal to orientate the reader in a manipulative way.

It is our contention here that both lexical and visual elements constitute a true reflection of the position of the journalist towards immigrants, namely, to portray them as problematic and associated with illegal activities, or rather, to offer a positive image of immigrants, free from prejudices or stereotypes. The analysis of immigration-related multimodal texts that we will carry out here would appear to be justified since, to the best of our knowledge, apart from our own contribution to the subject (Martínez Lirola 2008a), no other study has so far focused exclusively on the ways in which lexical and visual elements combine in the press to characterize immigrants, transmit certain ideological codes and values and, by so doing, exert social control.

The present paper is organized as follows. After briefly dealing with the corpus data and considering the theoretical paradigms on which our study relies, we will analyse how the lexical devices and images encountered in the news items of our corpus deal with the issue of immigration. The conclusions and the final results obtained from the analysis will bring this study to an end.

\section{Corpus}


As stated above, our study makes use of the local press in the province of Alicante. Alicante has not been chosen at random, but can actually be considered a prime example of the significant presence of immigration in Spain; indeed, it is the main recipient of immigrants in the Region of Valencia and has one of the highest percentages of immigration of any Spanish province. ${ }^{5}$ This immigration is not only present in Alicante, a traditionally multicultural and cosmopolitan town, but also in the whole province, where there are villages in which immigrants constitute a very high percentage of the population (see Gómez Gil 2003: 35-41).

Our analysis is based on a selection from 68 news items concerning immigration found in the daily newspapers La Verdad de Alicante and Información published in March 2008. In an attempt to minimize variables, the selection of the newspapers for this study was limited by certain parameters: they are regarded as serious newspapers ${ }^{6}$, they belong to the same year and the same month, and both are aimed at a spectrum of local readers from Alicante and its province. With regard to the news items dealing with immigration, $55 \%$ are multimodal texts and $44 \%$ are just written texts. In order to set a practical limit, we have selected eight texts from the 68 news items (see appendices) in which words and images interact to deal with immigration, and have focused on the headline, the subheading(s) and the caption of each news item, as pointed out in the introduction.

We should make it clear that the study presented here can make no claim to being complete or exhaustive. Indeed, the limited scope of the present essay, the logical space limitations and, above all, the number of newspapers that constitute our corpus do not allow us to reach valid conclusions in quantitative terms. Our analysis is therefore mainly qualitative, following the tradition of critical discourse analysts, who have usually relied on small data samples, as Hakam (2009: 36) notes. Despite this, we strongly believe that the sample of 68 news items consulted offers significant results regarding the representation of immigrants in the Alicante press.

\section{Theoretical frameworks}

We live in a society in which multimedia elements predominate. Texts that surround us are usually made up of two elements (i.e., two modes): the linguistic (language) and the visual (photographs, diagrams, etc.). The increasing prevalence of multimodal texts and multimodal communication raises the need to develop new literacies as a means of enabling readers to question the texts they are exposed to in their daily lives. Consequently, in recent decades, there has been an increasing interest in analysing ways of communication different (and alternative) to the written language. Baldry (2000), Kress (2003), Kress and Van Leeuwen (2001) and Unsworth (2008), just to mention a few, highlight the multimodal nature of contemporary societies, in which meanings are expressed through a combination of different semiotic resources, i.e., gestures, sounds and images together with language. For this reason, it seems necessary to analyse "how the modes of image and writing appear together, how they are designed to appear together and how they are to be read together." (Kress 2003: 61). Keeping this dual nature of texts in mind, we will rely on both Critical Discourse Analysis and Visual Grammar as theoretical frameworks used in the analysis of the lexical and visual elements present in the texts of our corpus.

Critical Discourse Analysis takes social reality as its reference; to be more precise, it focuses on the manifestations of conflict, dominance and discrimination in relation to textual structures and contextual clues. Following this approach, we 
understand language as social behaviour and thus related to social structure. In this sense, language is understood as a social activity that is developed through the different functions it performs and through the structures used to perform these functions. Consequently, language may be regarded as both social practice and a mode of social action insofar as it is capable of expressing meanings in different sociocultural contexts. In this way, language has potential behaviour, i.e., it determines the behaviour that speakers or writers of a particular language can perform, and it is a social event having a direct influence on the context in which it is used.

According to Van Dijk (2000a), Critical Discourse Analysis is overtly biased insofar as it is clearly on the side of the dominated groups; it is therefore especially suited to the study of immigration, an issue so prone to discrimination and unequal power relations. Within this framework, we find the "social-theoretical" sense of discourse developed by Fairclough (1992) especially useful for our purpose here. This scholar offers a three-dimensional concept of discourse, i.e., discourse as a piece of text, discourse as an instance of discursive practice and discourse as an instance of social practice: "My three-dimensional approach enables relationships between discursive and social change to be assessed, and detailed properties of texts to be related systematically to social properties of discursive events as instances of social practice" (Fairclough 1992: 8). In this sense, Fairclough's socially_and linguistically_oriented view of discourse allows us to relate the linguistic elements found in pieces of news to social values and ideologies concerning immigration.

As discourse is manifested in the linguistic form of a 'text' in the conception postulated by Fairclough (1992: 71), we will consider here the pieces of news as goaloriented texts with a social purpose. From this perspective, the news items can be viewed as instances of functional language, i.e., language that is doing some job in some context (Halliday 1985: 10), insofar as the verbal devices perform a particular function in their context; to be more precise, the journalistic texts can be said to be socially oriented, and their social purpose is likely to be deciphered by exploring their observable elements and patterns.

Together with lexical elements, it is also necessary to learn how to interpret images. To this end, we will rely on Visual Grammar, developed by Kress and Van Leeuwen (2006), as the theoretical basis for the analysis of visual elements. Following these scholars, there are three main means of composition in multimodal texts, namely, 'information value', i.e., the place in which elements are located, for example, from left to right, from top to bottom, or from the centre to the margins, can add a determined value; 'salience', i.e., the different elements of a composition try to catch the readers' attention, for example, appearing in the first or in the second position, the size of an element, the colour contrast or sharpness; and 'framing', i.e., the presence or absence of frames that connect or disconnect elements, meaning that they go or do not go together. Paying attention to these three means of composition, the main elements to analyse a multimodal text that we shall bear in mind in our analysis of the images found in the pieces of news are: the page layout, the headlines, subheadings and captions, the salience or main characteristic, the frames that the page has, and the photograph or image. Thanks to this analysis, we will get to know, among other things, who the people represented in the images are, and what values or beliefs are associated with them.

The discourse of multimodal texts places emphasis on modes of representation which are not written, especially on the visual mode to catch people's attention. This implies that we have to consider how the visual element and the contexts surrounding a text contribute to the experience we, as readers, have of a text. In fact, in this paper we will analyse texts taking into consideration that the interpretation is structured not only 
by 'what the text says', but also by contextually specific rules of interpretation which are contextually bound, as Van Leeuwen (2005: 83) points out.

Prior to analysing how verbal and visual elements are used in the newspaper coverage of immigrants and immigration, we will briefly explain how words and images contribute to the verbal and visual manipulation of the press.

\section{Verbal and visual manipulation of the press}

It is generally accepted that news bias is unavoidable. However, as Parenti (1997) argues, media bias does not occur in random fashion; rather, journalists choose the lexis and the images of news items with a clear purpose: to persuade or manipulate. After all, reporters have the power to influence the content of the newspaper and its social and ideological perspective. In fact, the majority of the pieces of news on immigration are mediatized (Van Dijk 2007, 2008) through the choice of words or images. From this point of view, the press can be said to be responsible in the creation and proliferation of ways of portraying immigrants. As the majority of our social and political knowledge and beliefs about the world come from the different pieces of information that we read or listen to through the media, by paying attention to the characteristics of the different linguistic and visual choices present in news items, we can get an insight into the power of the written press to influence readers and shape public opinion.

In this regard, the press has the power to make a specific image of immigrants credible and ultimately shape public opinion concerning immigration, given the impact serious newspapers have on public opinion. Therefore, the press can be said to carry out a process of social legitimization and acceptance of a particular view of immigrants, which is not always fair. In this process of social legitimization that serious-minded newspapers carry out, at the linguistic level euphemism and dysphemism are very useful devices at the journalist's disposal to portray immigrants; indeed, such lexical devices constitute the reflection of social codes and values. Journalists thus resort either to euphemism (i.e. the semantic or formal process thanks to which the taboo is stripped of its most explicit or obscene overtones) or to dysphemism (i.e. the process whereby the most pejorative traits of the taboo are highlighted with an offensive aim to the addressee or to the concept itself). Though to resort to the explicit advocacy of dysphemism is not very common in the serious press on which this study is based, euphemism is not trustworthy in all cases. Indeed, euphemism is a strategic device of politically correct (PC) language, very common in official language or public discourse. Burridge (2004:

206) defines PC language as "conformity to current beliefs about correctness in language and behaviour with regard to policies on sexism, racism, ageism, etc." Put simply, PC language makes the negative appear positive or at least tolerable and is a means of avoiding responsibility for what is said and the idea hidden behind the words. In this sense, euphemism is at the journalists' disposal to implicitly transmit an idea without departing too far from the appearance of objectivity and-what is more important—without damaging their own public image (Gómez Sánchez 2005).

In any case, to opt for one of these semantic resources constitutes an indirect expression of implicit values and affective meaning. Indeed, we should bear in mind that the connotative value of lexical units is much more significant than their purely denotative value. In this regard, euphemism and dysphemism can be considered as antithetical resources of referent manipulation ${ }^{7}$ in the social use of language, and useful devices in the condescending and preventive discourses on immigration, as Bañon Hernández (2002) has demonstrated. After all, rather than being instruments of 
exposition of ideas, euphemism and dysphemism are persuasive devices used to carry out ideological and social control depending on the journalist's intention and the interests of the owner of the newspaper. From this it can be deduced that language is far from being powerless. It actually moulds perception, culture and attitudes and does not merely mirror social reality, which is quite important in hegemonic struggles and very useful for ruling groups. In other words, as Kress (1989) maintains, language is an instrument of social power:

Because of the constant unity of language and other social matters, language is entwined in social power in a number of ways: it indexes power, expresses power, and language is involved wherever there is contention over and challenge to power. Power does not derive from language, but language may be used to challenge power, to subvert it, and to alter distribution of power in the short or in the longer term (p. 52).

As far as visual manipulation is concerned, following Van Leeuwen (2000: 333 ff.) and his concept of visual racism, we will use the term visual dysphemism to refer to the cases in which images show the pejorative side of a social reality or group of people. Some journalists choose some visual forms instead of others and this choice has a clear influence on the creation of meaning. In other words, they manipulate images in order to create visual dysphemisms in different ways, i.e., representing immigrants looking down and not interacting with the reader; showing immigrants' faces blurred; offering small images and presenting them in non prominent positions on the page (mainly on the left); not framing the visual texts concerning immigrants properly, so that they are not highlighted; presenting a dark background or not showing a clear contrast between the background of the image and the immigrants represented, etc. The idea hidden behind the use of visual dysphemism is that there is a superior world (that of the majority) and an inferior world (that of immigrants), and it is the superior world's ideology that usually transmits the immigrants' image. In general, visual dysphemism implies discrimination towards the group of people represented in the image, i.e., immigrants in our case, and usually combines with lexical dysphemism in the expression of offence and disrespect.

In the analysis presented in the next section, we will examine the way visual and verbal elements found in the texts that make up our corpus offer a particular image of immigrants and immigration.

\section{Analysis of the corpus}

In what follows, we will analyse how textual and visual elements are used in the representation of immigration and immigrants in the news items used as corpus. Our analysis of each multimodal text is divided into two parts, which are complementary to each other: the first one refers to the visual element of the multimodal text and the second part is basically focused on the lexical devices appearing in the text. Though for the sake of clarity visual and verbal elements are studied separately, it should be noted that these elements work together in the portrayal of a specific image of immigrants in each of the eight multimodal texts analysed, in spite of the fact that in many cases there is an apparent contradiction between visual and lexical elements, as we will see in the course of our analysis.

As pointed out in the introduction, we will concentrate on the headline, subheading(s) and caption of the news items that make up our corpus, as the image-text relationship characteristic of multimodal texts is more obvious in the case of the verbal 
elements appearing in these components of the news item. We should also bear in mind that the lexical analysis carried out in what follows basically focuses on euphemism, as this persuasive device of affective meaning is primarily used to carry out ideological and social control, rather than being merely an instrument of exposition of ideas.

\subsection{Text 1: Información, 3 March 2008, p. 3}

The first image (see Appendix A) appears in the top centre of the page, which is quite common in this newspaper. There is no clear contrast between the background of the image and the two immigrants that appear in it. New information appears on the righthand side of the page so that it is made more prominent. This implies that new information concerns the black person that appears at the bottom of the image on the right. This immigrant looks at the reader, i.e., there is interaction between him and the viewer, whereas the other worker that appears on the left hand side is facing away, which prevents any possibility of interaction with the reader. We find here a case of visual dysphemism. The fact that the immigrant is represented as distant and not having eye contact with the reader implicitly contributes to the immigrant's social exclusion in the sense that "his problems are not ours". Indeed, this representation of the immigrant can be interpreted as a way of placing the world of immigration far from local people's daily lives.

The way to read this multimodal text is from the right hand corner at the bottom of the image to the left hand corner at the top of the image. The image is quite big but the frame is not strong. Thanks to the fact that the image is quite big, located at the centre of the page and the background is quite clear, it can be observed that the immigrants are working in the building industry. This representation of the two immigrants as workers and, therefore, as active and productive citizens, tends to favour a positive attitude towards the immigrants on the part of the readers.

The lexis also reflects this positive view of immigrants as active workers. Indeed, this idea is verbalized in the caption ("Dos inmigrantes trabajan en una obra" 'Two immigrants are working on a building site') and is also present in the headline, which alludes to the fact that immigrants contribute to the economic growth of the province in a decisive way ("Los inmigrantes aportan el $60 \%$ del crecimiento de la economía de la provincia" "Immigrants contribute $60 \%$ of the economic growth of the province'). Similarly, in the subheading, the journalist resorts to a euphemistic lexical alternative to refer to immigrants that emphasizes their condition as foreign workers: the polisemic noun phrase trabajadores extranjeros ('foreign workers'). The euphemistic force of these lexical units lies in their intentional and deliberate ambiguity (Chamizo Domínguez 2004). Such ambiguity leads the reader to explore beyond the literal meaning and arrive at the connotations hidden behind the terms or phrases employed by the journalist. Consider the use of the noun phrase trabajadores extranjeros as it appears in the subheading of the multimodal text:

(1) Los trabajadores extranjeros han ocupado más de la mitad de los puestos de trabajo creados en la Comunidad Valenciana desde el año 2000.

'Foreign workers have occupied more than half of the jobs created in the Region of Valencia since 2000.'

In this citation, the ambiguity of trabajadores extranjeros plays a crucial role in euphemistic mitigation insofar as it enables immigrants to be given the same lexical 
label as other foreigners, say German residents in Alicante for instance, who are not associated with the discrimination and poor living conditions of a high percentage of immigrants. What is more, this noun phrase even serves to hide the very condition of immigrants. In this regard, euphemism can be said to carry out a function of social dignity (see Crespo Fernández 2008: 58) in an attempt to raise the social status of immigrants. However, readers should not be misled or deceived by an apparently inoffensive euphemistic disguise. "Los trabajadores extranjeros han ocupado más de la mitad de los puestos de trabajo" in (1) is merely an example of politically correct (PC) language whereby the journalist transmits an idea which is too explicit to be stated plainly: immigrants are responsible for unemployment in the Region of Valencia insofar as they take jobs away from Spanish citizens. Hence, the use of euphemistic lexical labels in texts which do not truly benefit the integration of immigrants in society (as also happens in some of the multimodal texts that we will analyse later) is a useful device to transmit prejudices against immigration in a socially acceptable way.

The analysis of this multimodal text shows that both positive elements and negative ones coexist in the representation of immigrants, as happens in many of the texts under analysis. Indeed, this multimodal text includes a contradictory image of immigrants, which has an intention for the reception process: the image of the immigrant far from the viewer and not looking at the camera is construed by the author as a dysphemism, but lexical aspects of the text are seen as euphemisms, as we have just pointed out. This seemingly positive message conveyed by the euphemistic lexical alternative is in apparent contradiction with the visual choice and with the connotations hidden behind the euphemistic term. This contradiction adds to the manipulative effect of the multimodal text under consideration insofar as it implicitly transmits - in a socially acceptable way - the message that immigrants are responsible for unemployment in the Region of Valencia.

\subsection{Text 2: La Verdad, 5 March 2008, p. 30}

The second photograph (see Appendix B) appears in the centre of the page. It is quite big because the article covers the whole page. It is black and white and shows three levels, i.e., foreground, in which almost all of protagonists are facing away, except one, whose face cannot be distinguished because the fence covers it; midground, with the people featured in the middle of the page, to the right; and background, with more people shown.

The protagonists appear covered by the fence, most of them are wearing a white T-shirt and dark trousers, and none of them are looking at the reader. More clearly than in the preceding text, the fact that the immigrants fail to look directly at the reader does little to encourage a positive view of immigrants, who seem to be ashamed of their situation; what is more, the fact that immigrants are behind a fence implicitly supports their social exclusion insofar as they are represented apart from the main group, and consequently, not integrated in society. This fence stands for the barrier that is erected between Spanish citizens and immigrants; a barrier that excludes them from the rest of society and leaves them in isolation. ${ }^{8}$ This way to represent immigrants implies a covert discrimination towards the group of people appearing in the image, which constitutes a significant case of visual dysphemism.

New information appears in the whole image and the way to read this multimodal text is from the left hand corner at the top of the image to the participants that appear in the midground, and from there to the left hand corner at the bottom of the 
image, i.e., there are two vectors that join all the immigrants that appear in the text. These two vectors have the purpose of representing immigrants at the same level, in other words, as individuals belonging to the same social group. The image is quite big but the frame is not strong, which helps to link the image to the written text, i.e., to present the different elements that constitute the multimodal text as a unity. The background is not very clear and it is only through the headline that we can distinguish where immigrants are.

As far as vocabulary is concerned, the lexical references to immigrants without legal documents are basically euphemistic. The term extranjeros, which appears in the caption of this news item, aims at veiling the illegal status of the immigrants, as in Text 1 discussed above:

HACINADOS. Inmigrantes en el centro de internamiento para extranjeros de Hoya Fría (Tenerife).

'CROWDED TOGETHER. Immigrants in the internment centre for foreigners in Hoya Fría (Tenerife).'

In the same vein, in the subheading the euphemistic periphrasis extranjeros que carecen de papeles ('foreigners without legal documents') tends to disguise the illegal status of those living in immigration centers:

$$
\begin{aligned}
& \text { El parlamento de la Unión pide flexibilizar el "desproporcionado sistema } \\
& \text { carcelario" al que son sometidos los extranjeros que carecen de papeles. }
\end{aligned}
$$

'The European Parliament demands an easing of the "disproportionate prison system" to which foreigners lacking documents are subjected.'

These examples provide evidence for the fact that the journalist is clearly aware of the hard living conditions of undocumented immigrants, who are crowded together in internment centres and treated as if they were criminals, which is unfair. In cases like these, in which immigrants are regarded as victims, the empathy of the journalist is strategic and encourages a positive response on the part of the reader (Van Dijk 2003: 107). By doing so, the fact that the immigrants are illegal and lack a residence permit becomes a matter of lesser importance.

This view of immigrants as victims is not totally positive, though; this feeling of compassion indirectly erects a barrier between the immigrants and the readers, who feel that they do not have anything to do with the group they are sorry for. For this reason, the discourse of compassion cannot be said to favour the integration of immigrants into Spanish society; rather, it widens the gulf between the immigrant and the Spanish citizen and is simply a pretext to justify the inhibition of the latter. This gulf between Spanish citizens and immigrants is visually represented in the fence, which reinforces the effect of social exclusion and marginalization that we commented on above.

\subsection{Text 3: La Verdad, 6 March 2008, p. 19}

The third picture (see Appendix C) shows three men working in the building industry. The three of them are looking down and facing away from the reader, which means that they is no interaction. One of the immigrants is bowed and the three of them are looking down. Besides, there is a fence that half covers them. The fence seems to be in the 
foreground, together with the three men. The background is a grey building that is a bit blurred. As in the two texts already analysed, this image constitutes a case of visual dysphemism in that it would appear to emphasize the social exclusion of immigrants. However, we should also bear in mind that this image is big and appears at the top of the page and in the centre. In addition, the background is very clear and it can be observed that the immigrants are working in the building industry. This representation of immigrants as workers-which has its lexical counterpart in the caption, as we will discuss later-together with the position of the photograph at the top of the page tends to favour a positive representation of the immigrants.

There is a vector at the top of the image that joins the heads of the three men; the beginning of the fence in the middle of the photograph is another vector that joins them; and finally the platform where they are standing up performs the same function. The fact that there are three marked vectors emphasizes the idea that the three men represented belong to the same social group, i.e., they are immigrants. Joining them through vectors implies not only that they are doing the same job, but also that they are individuals from similar social classes who share values, goals, expectations and educational background. The way to read the image is from the head of the person on the left to the person on the right. Since the person on the right is less covered by the fence than the others and appears where there is new information, he is given more prominence.

The vocabulary of this text, related to the problem of unemployment among immigrants, is basically euphemistic and thus reinforces the positive view of immigrants as workers in the photograph commented on above. The lexical units employed to refer to immigrants are trabajadores inmigrantes ('immigrant workers'), extranjeros ('foreigners') and inmigrantes ('immigrants'). The fact that the immigrants represented in the image are workers is emphasized in the caption of this news item, in accordance with the image, as commented on above. The text of the caption is the following:

(4) Trabajadores inmigrantes en el encofrado de un edificio en construcción.

'Immigrant workers in the framework of a building under construction.'

In the same vein, the use of the euphemistic term extranjeros in the headline is, at least in theory, positive for the image of the immigrants. Indeed, the euphemistic basis for the use of the polysemic term extranjeros lies in its ambiguity that leaves a door open to a more favourable interpretation, as commented on in Text 1 . In fact, extranjero does not present certain semantic traits that the word immigrant is associated with (poverty, illegality, marginality, discrimination, racism, etc.). Consider the headline:

$$
\text { La Comunidad Valenciana es la segunda con más extranjeros en paro. }
$$

'The Region of Valencia has the second highest unemployment rate for foreigners.'

In this sentence, it should also be noted that the journalist resorts to the euphemistic periphrasis procede de algún país exterior ('comes from abroad') in the subheading, a euphemistic periphrasis that is deliberately ambiguous in order to avoid any specific reference to the origin of immigrants: 

desempleados, uno de cada tres nuevos parados en enero procede de algún país exterior.

'[...] in the province of Alicante, where there are 15,094 unemployed immigrants, one out of every three new unemployed people comes from abroad.'

However, we should bear in mind that the euphemistic items commented on so far do not totally help to offer a positive representation of the immigrants or benefit their integration into Spanish society, the same as happened in Text 1. Rather, the high rate of unemployment among immigrants is emphasized, which may lead the reader to think of the serious consequences this may have for the social order. In this vein, the use of the number of unemployed immigrants apparently makes this information more credible and tends to aggravate the problem. However, as Aierbe (2006: 292) argues, the use of numbers does not really reflect the real quantitative dimension of the topic being dealt with; instead, it serves to reinforce the idea of a problem which is out of control.

\subsection{Text 4: La Verdad, 11 March 2008, p. 37}

As in the previous text, the fourth image (see Appendix D) shows three men working in the building industry who are facing away from the reader, so that there is no interaction. Indeed, we can only see half of the face of one of the workers. There is a thick fence that covers the bodies of two of the three immigrants represented. From all this we can deduce that the visual element in this multimodal text conveys a negative view of immigrants, in a clear example of visual dysphemism. Not only because immigrants are represented behind a fence - a physical barrier between them and the viewers, as in Text 2 -, but also because they avoid any eye contact with the viewer. In addition to this, as we will explain in the analysis of lexical elements, the heading and subheading, which emphasize the rise in unemployment among immigrants, do not favour their integration into society. This negative representation is reinforced by the fact that the photograph appears in the second part of the page. Moreover, as the image is not very big and the immigrants appear mixed up with the background, they can hardly be recognized, which also tends to favour their isolation from the privileged social groups. The immigrants are wearing dark trousers and white T-shirts, except for one who appears without a T-shirt revealing his dark skin, which makes it clear that he comes from a different country.

There is a vector that joins the participant represented at the bottom of the image with the participant with no T-shirt. In this way, although one of the three men represented appears at a different level and only half of his body can be seen at the bottom of the image, the vector makes it obvious that they are doing the same job and belong to the same social group, as in the images already analysed. The way to read the image is from the person on the right at the bottom of the page to the person in the middle, and finally the person on the left in the middle of the page. The image is smaller than the three already commented on, which implies that the written text is given more importance in this multimodal text. The background is quite clear and it can be observed that the immigrants are working in the building industry.

As in the preceding text, this one presents a euphemistic vocabulary to refer to unemployed immigrants; namely, they are referred to as extranjeros en paro 
('foreigners out of work') in the headline, desempleados extranjeros ('unemployed foreigners') in the subheading and trabajadores extranjeros ('foreign workers') in the caption. Despite the use of euphemistic vocabulary to refer to immigrants who are out of work, the journalist seeks to draw the reader's attention to the dramatic situation of unemployment among immigrants with a headline like the following one, highlighted in bold:

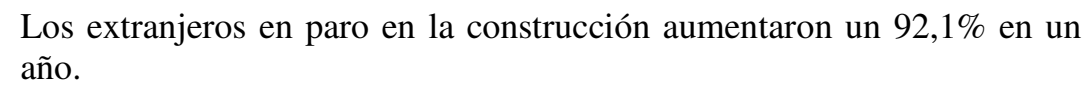

'The number of foreigners out of work in the building industry has increased by $92.1 \%$ in one year.'

By means of this headline, readers receive dramatic information, which may compel them to fear immigrants; in fact, the message which is implicitly transmitted is that the increase of unemployment among immigrants may lead to serious social problems. This view of immigration as a threat is reinforced in the subheading, as the journalist states that the Region of Valencia is one of the four regions in Spain with the highest rate of unemployment among immigrants. We should not forget, after all, that the reader of this newspaper lives and works in Alicante, one of the provinces of this region. The caption reads as follows:

$$
\text { Cataluña, Madrid, Comunidad Valenciana y Andalucía concentraron más }
$$
de la mitad de los desempleados extranjeros.

'Cataluña, Madrid, the Region of Valencia and Andalucía accounted for more than half of the total number of unemployed foreigners.'

From this point of view, and despite the use of euphemism, immigrants are seen as a threat to security, social cohesion and the welfare system. As happens in (6) and (7), the use of the number and percentage of unemployed immigrants tends to make the problem appear more serious and activates racist and discriminatory prejudices against them.

\subsection{Text 5: La Verdad, 17 March 2008, p. 19}

The multimodal text presented in Appendix $\mathrm{E}$ is clearly ambivalent insofar as it combines visual dysphemism with lexical euphemism, as will be explained in what follows. As far as the visual element is concerned, the immigrant receives a negative treatment because of different elements, namely, the picture is rather small and the immigrants represented cannot be clearly distinguished; it appears in the bottom righthand corner of the page; the frame is not very pronounced; there is no clear contrast between the background of the image and the different immigrants that appear there because the background is dark and the immigrants are wearing dark clothes; new information appears on the right-hand side of the photograph, and this is the reason why the immigrant in the foreground is made more prominent. This implies that the most important part of the information concerns the black person that appears lying down at the bottom-right of the image, probably in need of medical care. This image makes the reader appear industrious compared to immigrants, who are shown as weak and dependent on others, that is, as a burden on society and social welfare. Finally, the fact that none of the immigrants represented are looking at the reader, i.e., there is no 
interaction between them and the reader, does not benefit the social integration of immigrants either.

All the immigrants that appear in the background (some of them are standing up and others are sitting down), on the left-hand side, are looking to the left where there might be something happening. Whatever is happening is not shared with the reader. In the middle of the group of immigrants there is a woman, probably belonging to a NGO; she is clearly distinguished by a waistcoat. There is a vector joining her with the two immigrants that are standing behind her. Since the three of them appear in the middle of the image and are looking to the left, the purpose of the vector is to show that the people represented are focusing on something happening at that time that does not appear in the photograph, which is therefore not shared with the reader of the multimodal text.

Despite the fact that visual elements do not offer a positive view of immigrants, verbal elements cannot be said to represent them in negative terms. Judging from the vocabulary used in this text, the journalist seems to be aware of the dramatic situation a group of African immigrants who have just arrived in Tenerife are going through. Indeed, the illegal status of these immigrants is downtoned by the use of the generic term personas ('people') in the headline. This term implies a generalization of the referent and, by doing so, tends to hide the illegal status of the immigrants:

Un cayuco con 56 personas, once de ellos menores, llega a Tenerife.

'A cayuco boat with 56 people on board, eleven of them minors, arrives in Tenerife'

Here the term personas reminds the reader of the obvious fact that those immigrants, whether arriving illegally in the country or not, are human beings and should be treated as such. In the same vein, though the term immigrants can be said to be a negatively loaded word on many occasions in the discourse related to immigration, as commented earlier in the analysis of Text 3, this does not seem to be the case in the text of the caption that accompanies the image:

OTRO CAYUCO. Algunos de los inmigrantes llegados a Tenerife.

'ANOTHER CAYUCO BOAT. Some of the immigrants who have arrived in Tenerife'.

In this caption, the word immigrants performs a clear euphemistic function. Its mitigating force is based on the fact that not all immigrants who live in Spain lack a residence permit. In this sense, as in the case of the term personas in the headline, the irregular status of the immigrants who have arrived in Tenerife is hidden.

\subsection{Text 6: La Verdad, 19 March 2008, p. 24}

The sixth image (see Appendix F) appears at the top centre of the page, which is quite common in this newspaper. There is a contrast between the background of the image and the five people that appear in it because one of them has a lighter to illuminate both the immigrant that is sick and the medical staff. New information appears in the centre of the page concerning the black person who is at the bottom centre of the image. He is the only person showing his face; the three people surrounding him are looking down and the head of the person standing up with the lighter is not in the picture. 
None of the people are looking at the reader and the four people that are trying to help the immigrant that is in the centre of the image are looking at him. The fact that the black immigrant appears in the centre, surrounded by three people who are helping him and illuminated by the person with the lighter shows that he is the most salient element in the picture. He is even more highlighted because he is lying on the floor. Though the reader may feel sorry for the unconscious woman lying on the floor, the representation of this immigrant in need of medical care implicitly transmits the view of the immigrant as a burden on society and social welfare, as in the case of the immigrants represented in Text 5. Besides, this view of the immigrant ultimately confirms the breach between immigrants and readers, between us and them, between Spaniards and foreigners.

There is a vector that joins the three heads of the participants surrounding the immigrant. This vector is interpreted as a means of emphasizing that there are three people cooperating and working together to give the immigrant medical care. The way to read this multimodal text is from the centre at the bottom of the image to the right hand corner at the top of the image. Consequently, the black person who is sick is made more salient because he is at the centre of the image receiving the light from the person who is standing on the right carrying a lighter and because he is surrounded by the three people who are doing their job. The image is quite big and there is a frame that joins it with some lines that refer to the arrival of some immigrants in Tenerife. In this way, the idea of the multimodal text as a whole, that is, as a complementary contribution of image and word to the meaning-making process, is highlighted.

In the text corresponding to the image commented on above there is no pejorative reference to the illegal status of immigrants. Indeed, despite the representation of the immigrant as weak and dependent on others, the euphemistic phrase inmigrantes llegados a Canarias ('immigrants that arrived in the Canary Islands') in the caption has a clear purpose: to avoid mentioning the fact that these immigrants have arrived in Tenerife without legal documents:

(11) RESCATE. Sanitarios atendiendo a uno de los inmigrantes llegados de madrugada a Canarias.

'RESCUE. Health workers assisting one of the immigrants that arrived in the Canary Islands before dawn'.

In a case like this, the journalist resorts to the euphemistic reference in the hope that the illegal status of the immigrants will be overlooked, as in Text 5 already discussed.

\subsection{Text 7: La Verdad, 25 March 2008, p. 12}

The seventh image (see Appendix G) appears in the top centre of the page. There is a clear contrast between the background of the image, and the seven people that appear in the foreground. New information appears on all the people shown, especially on the two fishermen from Senegal. All the people have a positive attitude and are looking at the camera.

There is a clear vector that joins the seven people featured, underlining the fact that although there are people from different nationalities among them, they share the same job; therefore, the vector helps to portray the seven people on equal terms. They are organized in three groups: two people (one of whom is a woman) appear on the right-hand side of the image, another two on the left-hand side, and three in the centre. 
This division helps to make the three parts into which the photograph is divided more distinct: the centre, the left-hand side (the part of the image that is given less importance) and the right-hand side (the part of the image that is given more importance). In consequence, the way to read this multimodal text is from the centre, where there are three people, to the margins. The image is quite big but the frame is not pronounced, which enables the reader to interpret the written text and the image as a whole. The background is clear and it can be observed that the seven people are posing for the picture. From this description of the photograph it can be deduced that the image of immigrants transmitted here is totally positive.

In line with this positive representation of immigrants transmitted by visual elements, in this multimodal text there is also a positive lexical treatment towards immigrants, who regarded as disciplined fishermen. In this vein, they are referred to as extranjeros ('foreign workers') and pescadores de Senegal ('fishermen from Senegal'). Take the caption of this news item:

(12) DE SENEGAL. Dos pescadores de Senegal se presentan a la tripulación de un arrastrero alicantino.

'FROM SENEGAL. Two fisheremen from Senegal introduce themselves to the crew of a trawler ship from Alicante'.

It is worth considering that the foreign origin of these workers is emphasized in the caption above, the same as in the headline and the subheading (see Appendix G). It is not only the foreign origin of these fishermen that receives special emphasis; in fact, references to work in the headline ("la flota pesquera alicantina" "the fishing fleet from Alicante'), in the subheading ("el sector se muestra muy satisfecho de los senegaleses, peruanos y marroquíes" "the sector is very satisfied with people from Senegal, Peru and Morocco') and in the caption, as seen in (12), emphasize the condition of immigrants as human beings and workers who contribute to the economy of the country just like any other worker. This view benefits their social integration regardless of their ethnicity, nationality or legal status.

\subsection{Text 8: Información, 25 March 2008, p. 19}

The eighth photograph (see Appendix H) appears in the middle of the page. The background of the image is blurred and one of the two people working there is mixed up with the background, which consists of plants in the countryside. New information appears on the right-hand side of the image, i.e., concerning the person that is working. $\mathrm{He}$ is the most prominent element of the image. However, he can hardly be distinguished, as his clothes are dark and he is surrounded by green plants. Besides, he is looking down and therefore does not interact with the readers. On the left-hand side of the image there is another worker, who can hardly be seen because he is covered by plants. His clothes are brown and he is also looking down. This representation of immigrants as people who avoid contact with the readers-a common feature in the corpus consulted-together with the fact that they appear mixed up with the background, tends to contribute implicitly to their social exclusion. In this particular case, the immigrants are excluded because they are taken as paradigmatic examples of foreigners outside the EU who work in the underground economy, that is, without a legal contract, as the subheading indicates. This may lead the reader to deduce that 
immigrants feel ashamed of their situation: they feel inferior to the main group and that is the reason why they are not looking at the reader.

There is a vector joining the heads of both people shown. In this way, the two human beings that appear in this multimodal text are connected and thus the vector helps to emphasize that they are doing the same job in the countryside. The way to read this multimodal text is from the right of the image, where the protagonist appears, to the left. Although both men are surrounded by plants, the fact that one of them appears on the right, i.e., the place of important and new information, serves to emphasize his active role as a worker in the countryside.

Not all visual elements in this text convey a negative view of immigrants, though. As happened in Texts 1 and 3, the fact that they are shown as active workers favours a positive representation of immigrants as citizens who work to earn their living and, by so doing, contribute to the economy of the country. In this positive vein, it should be mentioned that the image is quite big, which tends to reinforce this positive treatment of immigrants as active workers.

In line with the positive image of immigrants transmitted by these visual elements, the text accompanying the image is also favourable to immigrants. Indeed, the lexis employed is clearly euphemistic in its approach to immigrants working without a contract. Indeed, the fact of not working in legal conditions is somehow diminished under the euphemistic phrases sin contrato ('without a contract') and en la economía sumergida ('in the underground economy'). The latter appears in the headline of this news item:

$$
\text { Los inmigrantes pasan la mitad de su vida laboral en la economía }
$$
sumergida.

'Immigrants spend half of their working lives in the underground economy'.

Here the term inmigrantes is not a neutral or ortophemistic term, let alone a pejorative one, as it helps to conceal the illegal working conditions of these immigrants and thus reflects a positive attitude towards those immigrants working illegally.

Apart from the term inmigrantes, there are other euphemistic items which refer to illegal immigrants in this text. In the caption, we find the noun trabajadores ('workers'). It is a generic term whose function is to minimize the associations of immigration with illegality and poverty, and emphasize the fact that the only way to survive for these human beings is working without a work permit and usually under hard conditions. In other words, it emphasizes the notion that, after all, these immigrants are people who are working, the same as those who are doing it legally. The same euphemistic function is carried out by the periphrasis extranjeros de fuera de la UE in the subheading:

(14) Los extranjeros de fuera de la UE que residen en la Comunidad han trabajado una media de 4,92 años, de los que 2,28 lo han hecho sin contrato.

'Foreigners outside the EU residing in the Region have been working for an average of 4.92 years, out of which 2.28 have been without an employment contract.' 
As in Text 1, the ambiguity of the periphrasis extranjeros de fuera de la $U E$ provides the euphemistic support of the reference to immigrants residing and working without a contract. Indeed, the social status of such immigrants is dignified insofar as they are referred to in the same way as other immigrants from outside the EU who are generally believed to enjoy a high standard of living. Furthermore, by doing so, their very condition of immigrants is hidden under this lexical label in an obvious example of PC language.

\section{Conclusions and results}

What emerges from this piece of research is that immigrants tend to be represented in three main ways in the multimodal texts analysed: first, they are portrayed as a threat and a burden on society because they invade our territory, increase unemployment rates and reduce economic growth, among other "evils". In this case, readers are compelled to

reject them; second, they are represented as poor people living in a dramatic situation, in which case the reader shows compassion towards them; and third, though to a lesser extent, they are considered as workers who aim at earning their living and integrating into Spanish society. These ways of representation are transmitted through lexical and visual elements, as summarized in what follows.

As far as positive representations are concerned, there are some images and lexical elements that tend to benefit the image of immigrants. In Texts 1, 3, 4, 7 and 8, the immigrants are represented as workers and, therefore, as active and productive citizens. The fact that most of the images are quite big and appear at the top or the centre of the page (except Text 5, which appears at the bottom) also reflects this positive tone. The vocabulary found in these texts tends to reinforce this positive treatment on the part of the journalist. Indeed, the illegal status of immigrants is disguised under the euphemistic labels extranjeros and personas and the fact that they are workers is stressed through the lexical labels trabajadores extranjeros and pescadores. It is interesting to note that in the language of the captions, the idea of immigrants as workers is especially emphasized: immigrants are indeed referred to as trabajadores, pescadores, trabajadores inmigrantes and trabajadores extranjeros.

However, some visual and lexical elements transmit a negative image of immigrants and contribute, therefore, to their social exclusion. This is the case of those immigrants who are facing away from the reader, and thus do not interact, in Texts 1, 2, 3 and 4. Furthermore, the image of a group of idle immigrants spending the night in the street in Text 5 makes the reader appear more pro-active in comparison, and therefore with a more important social role. Besides, whenever immigrants are represented as sick and in need of medical care, as in Texts 5 and 6, they are shown as weak and dependent on others; in such cases, the feeling of compassion the reader may experience simply confirms the gulf between the immigrant and the Spanish citizen, and ultimately justifies the passivity of the latter concerning the delicate issue of immigration. The fact that the background of the image is blurred and the immigrants appear mixed up with the background means that they can hardly be recognized, as in Texts 4 and 8 . Consequently, their identity and importance as active citizens in society is somehow diminished, which does little to create a positive image of immigrants (Martínez Lirola 2008a). All these are cases of visual dysphemism, as these images tend to offer a negative or, to say the least, non-positive, representation of immigrants and do not in any way benefit their social integration. 
Taking into consideration Bañón's (2002) classification of the main types of discourse about immigration that circulate in Spain, from our analysis we can conclude that the discourse types that are currently being legitimised are those of 'discrimination' and 'prevention'. This seems to be so because the majority of the multimodal texts analysed offer a negative or, at best, non-positive representation of immigrants, either for belonging to a social group that needs help and protection, or on account of being a threat to social welfare and social stability. Indeed, evidence from the corpus suggests that a considerable number of lexical and visual elements portray immigrants as individuals who do not match up to the standards of the host society, for some reason or another. In just one of the multimodal texts analysed, however, the type of discourse falls within the category of 'compromise', as the journalist offers a positive view of immigrants as active and responsible workers through visual and verbal modes of communication. ${ }^{9}$

It is also interesting to note that euphemistic references to immigrants do not necessarily transmit a positive image of immigrants. Indeed, in Texts 1, 3 and 4, euphemistic labels are examples of politically correct (PC) language and are merely instruments at the journalists' disposal to hide the true intention behind the words: to transmit the idea that immigrants are in part responsible for unemployment in Spain and constitute a potential threat to social order as well as a burden on the economy of the country. Indeed, certain texts in which journalists resort to euphemistic references to immigrants betray a series of ideological codes and values that damage the image of immigrants to a considerable extent. This can be also seen in the captions of such texts in which the journalists resort to neutral or ortophemistic lexical units, but never to overt dysphemistic or pejorative references to immigrants.

Despite the non-positive representation of immigration in most of the texts analysed, we should be somehow optimistic, as the portrayal of immigrants in the Spanish press is gradually improving; in fact, in an earlier study, we demonstrated that journalists in 2005 used to resort to pejorative terms like ilegales ('illegal immigrants') to refer to those immigrants lacking documents (see Crespo Fernández 2008). Besides, this study demonstrates that the number of news items that offer a positive view of immigrants is not as low as it has traditionally been. ${ }^{10}$

In short, the study of the different visual and linguistic choices employed has made us aware of the power of the press to influence knowledge, values and social relations concerning the issue of immigration. In fact, despite the presence of euphemism in captions, headlines and subheadings and the positive attitude of some journalists, we must be aware that, while not overtly offensive, some verbal and visual elements tend to provoke, whether consciously or not, discrimination towards immigrants. In this sense, the reader is invited to establish a clear difference between whites and other ethnic groups, between 'us' and 'them', between 'citizens' and 'immigrants', between 'Spaniards' and 'foreigners', which indirectly activates prejudiced attitudes and unfair stereotypes based on race, culture, religion or economic status.

\section{Notes}

\footnotetext{
* We would like to thank the anonymous reviewers of this paper for their insightful comments on an earlier version. We also want to express our gratitude to Clive A. Bellis, of the Department of English Studies, University of Alicante, for proofreading the paper.
} 
1. In this study, we understand by immigrants people belonging to an ethnic minority coming from poor countries, stigmatized and tending to social exclusion, though not all immigrants in Alicante are in this situation.

2. For a detailed analysis of immigration policy in Spain in recent decades, see Ortega Pérez (2003).

3. For a multimodal text to be well created, first, the different elements that compose the text (verbal and non-verbal) should be complementary, i.e., images should help to identify the context of situation; and second, everything that is part of the multimodal text (type of letters, place in which the image appears, vocabulary and structures used, etc.) should contribute to the creation of the sense of the text and influence the reader.

4. As an anonymous referee correctly observes, the discourse of the photographs and their captions is an interesting aspect to explore, as the terminology and descriptions in the captions orientate the reader in a manipulative way.

5. According to the INE (Instituto Nacional de Estadística) report, in 2007 there were 390,577 foreigners in the province of Alicante, most of them from Morocco, Equador and Colombia. This means that Alicante is the third Spanish province in quantitative terms as far as the number of immigrants is concerned, just behind Madrid and Barcelona.

6. We understand by serious newspapers those focused on serious journalism dealing with current political affairs and events, in contrast with less serious newspapers that generally deal more with subjects such as celebrities or sports.

7. Referent manipulation is the process whereby the language user presents the taboo concept in a particular way, either softening its less acceptable aspects or, on the contrary, intensifying them. The referent does not undergo any alteration in itself, though it is manipulated by the speaker or writer, and the result of this manipulation is what the receiver notices (for a full description of this process, see Crespo Fernández 2007).

8. As an anonymous referee points out, the image of immigrants behind a fence could implicitly support the view of immigrants as criminals and, in consequence, reinforce their social exclusion and marginalization.

9. In any case, one should bear in mind, as Bañón (2002: 33) points out, that the discourse types he refers to do not form clear-cut categories; rather, they form a continuum in which the different types of discourse are included.

10. In fact, Teun Van Dijk estimates that the percentage of news items in which immigrants are represented in a favourable way is extremely low, around 5\% (Martínez Lirola 2008b: 21).

\section{References}

Aierbe, Peio. 2006. "Trabajar en Red. La Agenda de la Diversidad”. Medios de comunicación e inmigración, ed. by Miguel Lario. Murcia: Convivir sin Racismo. 287-297.

Baldry, Anthony. (ed.). 2000. Multimodality and Multimediality in the Distance Learning Age. Campobasso: Palladino Editore.

Bañón Hernández, Antonio. 2002. Discurso e inmigración. Propuestas para el análisis de un debate social. Murcia: Universidad.

Burridge, Kate. 2004. Blooming English. Cambridge: Cambridge University Press.

Cottle, Simon. 2000. "Media Research and Ethnic Minorities: Mapping the Field". Ethnic Minorities and the Media, ed. by Simon Cottle. Philadelphia: Open University Press. 2-30.

Chamizo Domínguez, Pedro. 2004. "La función social y cognitiva del eufemismo y del 
disfemismo". Panacea 5 (15). 45-51.

Crespo Fernández, Eliecer. 2008. "El lenguaje de la inmigración. Atenuación y ofensa verbal en la prensa alicantina". Inmigración, discurso y medios de comunicación, ed. by María Martínez Lirola. Alicante: Juan Gil Albert. 45-64.

Crespo Fernández, Eliecer. 2007. El eufemismo y el disfemismo. Procesos de manipulación del tabú en el lenguaje literario inglés. Alicante: Universidad.

Fairclough, Norman. 1992. Discourse and Social Change. Oxford: Blackwell.

Gómez Gil, Carlos. 2003. La inmigración en Alicante y algunas de sus paradojas. Alicante: Universidad.

Gómez Sánchez, Elena. 2005. "Los sustitutos eufemísticos y la claridad del texto informativo". Estudios sobre el Mensaje Periodístico 11. 309-327.

Hakam, Jamila. 2009. "The Cartoons Controversy. A Critical Discourse Analysis of English-Language Arab Newspaper Discourse". Discourse and Society 20. 3375.

Halliday, M.A.K. 1985. Language, Context, and Text: Aspects of Language in a SocialSemiotic Perspective. Oxford: Oxford University Press.

Información (1 March 2008 to 31 March 2008).

Kress, Gunther. 2003. Literacy in the New Media Age. London: Routledge.

Kress, Gunther. 1989. Linguistic Processes in Sociocultural Practice. 2nd ed. Oxford:

Oxford University Press.

Kress, Gunther \& Theo Van Leeuwen. 2006. Reading Images: The Grammar of Visual Design. 2nd ed. London: Routledge.

Kress, Gunther \& Theo Van Leeuwen. 2001. Multimodal Discourse- The Modes and Media of Contemporary Communication. London: Arnold.

La Verdad de Alicante (1 March 2008 to 31 March 2008).

Martínez Lirola, María. 2008a. "Las relaciones entre las características lingüísticas y visuales de las noticias sobre inmigración en la prensa gratuita y la relación interpersonal con la audiencia". Discurso y Sociedad 2 (4). Available at http://www.dissoc.org (Accessed January 2010). 799-815.

Martínez Lirola, María. 2008b. "Entrevista al Profesor Teun Van Dijk". Inmigración, discurso y medios de comunicación, ed. by María Martínez Lirola. Alicante:

Juan Gil Albert. 15-21.

Ortega Pérez, Nieves. 2003. "Spain: Forging an Immigration Policy". Available at http://www.migrationinformation.org/profiles/display.cfm?id=97\#top (Accessed December 2009).

Parenti, Michael. 1997. "Methods of Media Manipulation". Available at http://thirdworldtraveller.com/Media/MediaManip_Parenti.html (Accessed October 2009).

Unsworth, Len (ed.). 2008. New Literacies and the English Curriculum. London: Continuum.

Van Dijk, Teun. 2008. "Reproducir el racismo: el rol de la prensa". La inmigración sale a la calle. Comunicación y discursos políticos sobre el discurso migratorio, ed. by Francisco Checa Olmos. Barcelona: Icaria. 19-49.

Van Dijk, Teun. 2007. "El racismo y la prensa en España”. Discurso periodístico y procesos migratorios, ed. by Antonio Bañón Hernández. San Sebastián: Tercera Prensa. 27-80.

Van Dijk, Teun. 2003. Ideología y discurso. Barcelona: Ariel.

Van Dijk, Teun. 2000a. New(s) Racism: A Discourse Analytical Approach. Ethnic 
Minorities and the Media, ed. by Simon Cottle. Philadelphia: Open University Press. 33-49.

Van Dijk, Teun. 2000b. "Análisis crítico de las noticias". Mugak 2. Available at http://revista.mugak.eu/articulos/show/15 (Accessed November 2009).

Van Leeuwen, Theo. 2005. Introducing Social Semiotics. New York: Routledge.

Van Leeuwen, Theo. 2000. "Visual Racism". The Semiotics of Racism. Approaches in Critical Discourse Analysis, ed. by M. Reisigl \& R. Wodak. Wien: Passagen Verlag. 333-350.

\section{Appendices}

(See separate file)

Authors' addresses

Eliecer Crespo Fernández

Department of Modern Philology

Faculty of Education

University of Castilla-La Mancha

Edificio Simón Abril

Plaza de la Universidad, 3

02071 Albacete

Spain

eliecer.crespo@uclm.es

María Martínez Lirola

Department of English Philology

Faculty of Arts

University of Alicante

Apartado de Correos 99

E - 03080 Alicante

Spain

maria.lirola@ua.es 